J. Perinat. Med. 14 (1986) 227

\title{
Effects of intraamniotically administered thyroxin on acceleration of fetal pulmonary maturity in preeclamptic toxemia
}

\author{
Ivan Veszelovszky¹, Zoltán B. Nagy ${ }^{1}$, and Lajos Bódis²
}

${ }^{1}$ Department of Obstetrics and Gynecology, Municipal Hospital, Szentes, and

${ }^{2}$ Department of Obstetrics and Gynecology, Municipal Hospital, Szeged, Hungary

\section{Introduction}

The role of idiopathic respiratory distress syndrome (IRDS) in perinatal death is proved by data published in various countries $[7,9,10$, $24,26,27]$. In view of the high incidence of premature births in Hungary as well as observations that it is premature birth above all which predisposes the development of IRDS, steroid prophylaxis remains in the center of professional interest $[14,16,22,26,27]$. As numerous side effects and risks for steroid administration is known $[10,18]$, other possibilities should be investigated for preventive medication. Wu et al. $[29,30]$ with laboratory animal experiments, MACHIACH et al. [11, 12, 21] in human subjects proved that other pharmacologic agents can be used. Intraamniotically administered thyroxin beneficially influences the development of pulmonary surfactant, and it is applicable for preventing IRDS. Since 1974 we have regularly used dexamethasone for IRDS prophylaxis; thus, we have had the opportunity to observe that in pregnancy complicated by toxemia, intrauterine death was more frequent following steroid prophylaxis. It seemed reasonable that for IRDS prophylaxis, thyroxin should be administered intraamniotically in pregnancy complicated by preeclamptic toxemia. Our purpose is to report our observations on the effects of

\section{Curriculum vitae}

Dr. IVÁN VESZELOVSZKY was born in 1938 in Zombor, Hungary. He studied medicine at Szeged University, Hungary. After graduation in 1964, he specialized in obstetrics and gynecology in 1968. In 1976 he was appointed as Head of the Department of $\mathrm{Ob}$ stetrics and Gynecology at the Municipial Hospital,

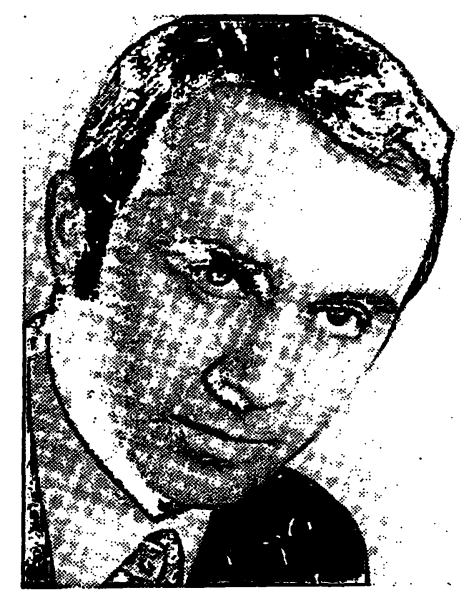

Szentes. He gained a scientific degree (Candidate for Medical Sciences) in 1980. His project was entitled "Prevention of Idiopathic Respiratory Distress Syndrome with Dexamethasone". Since 1985 he has been a titular docent of Szeged University. His main interests are perinatology and amniotic fluid analysis.

intraamniotically applied L-Thyroxin "Henning".

\section{Material and method}

Between January 1, 1982 and January 1, 1984 according to WITTLINGER, 18 cases of serious and fairly serious toxemic pregnancy were administered $500 \mu \mathrm{g}$ of L-Thyroxin "Henning" in a single dose intraamniotically after the laboratory findings of negative pulmonary maturity 
in the amniotic fluid. The ages of the patients were between 16 and 39 years with a gestational age of 29-40 weeks (mean: 36.3 weeks). Prior to the considered therapy but after the thorough clinical examinations of the mother, amniotic fluid was obtained by ultrasound-directed transabdominal amniocentesis with a PICKER LS 2700 ultrasound machine. After obtaining $30 \mathrm{ml}$ of amniotic fluid, the needle was left in place with sterile closing. For rapid determination, a Clements test was performed, and in case it showed pulmonary immaturity, via the same needle, $500 \mu \mathrm{g}$ of L-Thyroxin "Henning" was injected into the amnionic fluid. Removing the needle, the patient was kept under surveillance for 24 hours. Prior to thyroxin treatment, cholesterin test was made from cubital vein and the level of estriol, HPL, as well as $T_{3}$ and $T_{4}$ were determined by Ria method. The same parameters were examined 1 hour after thyroxin administration as well as every 24 hour interval up to parturition. After delivery, the same parameters were determined as well as the level of $T_{3}$ and $T_{4}$ from mixed blood from the umbilical cord. Besides the Clements test, as part of amniotic fluid analysis, the L/S ratio, amniocrit, glucose, creatinine, estriol and HPL values were determined. In every case the bacteriological examination of the amniotic fluid was performed. Forty-eight hours after medication the amniocentesis was repeated and the chosen parameters rechecked. When medically indicated, labor was induced. When the maternal/fetal state did not require induction, we awaited the onset of spontaneous labor while performing intrauterine examinations. After delivery $T_{3}$ and $T_{4}$ levels were determined from mixed cord blood.

During the postnatal period, the neonatologist kept the newborn under strict surveillance to observe any early possible side effects. In the 5 th day after delivery, from venous blood, the $\mathrm{T}_{3}$ and $\mathrm{T}_{4}$ levels were repeated by Ria method. It was not possible to measure $T_{3}$ levels from amniotic fluid because a precipitate was not obtainable from the tube.

The changes of the $T_{4}$ level and the $L / S$ ratio in the amniotic fluid as well as that of $\mathrm{T}_{4}$ in the cord were statistically analyzed by Student's $\mathrm{x}^{2}-$ test.

\section{Results}

The effect of the intraamniotically administered thyroxin on the various parameters examined is presented in table I. 48 hours after thyroxin administration, the $T_{4}$ level of the amniotic fluid showed an increase of extreme degree; the difference was very significant $(p<0.001)$. The maternal $T_{3}$ and $T_{4}$ levels did not change due to the medication (figure 1).

When the delivery occured 48 hours after medication, the $\mathrm{T}_{4}$ level gradually decreased in the amniotic fluid, and 5-6 days after thyroxin administration the $T_{4}$ levels practically showed the prior value. Forty-eight hours after thyroxin administration the $\mathrm{L} / \mathrm{S}$ ratio rose more then two times in each case (figure 2).

The $\mathrm{T}_{4}$ level in the cord blood taken after delivery, increased compared to the basic value but the difference was not significant $(p>0.05)$.

Table I. Effect of intraamniotically given L-Thyroxin "Henning" $(500 \mu \mathrm{g})$ on the examined parameters.

$$
\begin{aligned}
& \text { No change observed after } \\
& \text { administration of thyroxin }
\end{aligned}
$$

Change observed after administration of thyroxin
Fetal and amniotic

fluid, respectively:

- amniocrit

- estriol level

- creatinine concentration

- glucose concentration

- FHR
- Clements test (became positive)

- L/S ratio (rose)

- $\mathrm{T}_{4}$ level (rose at extreme rate)

- $\mathrm{T}_{4}$ level in cord blood*

* the increase is not significant. 


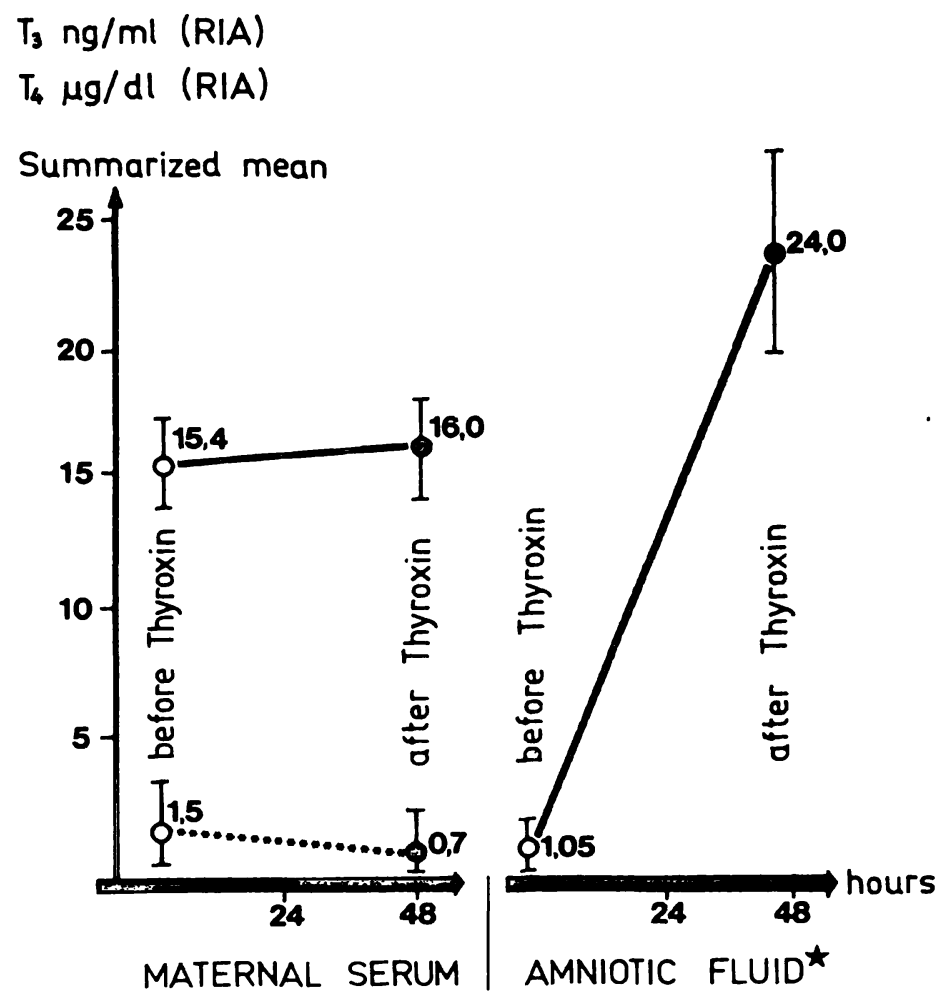

$\star T_{3}$ non-measurable in amniotic fluid

Figure 1. Level of $T_{3}$ and $T_{4}$ in maternal serum and amniotic fluid after $24-48$ hours intraamniotically given $500 \mu \mathrm{g}$ of thyroxin $(\mathrm{n}=18)$.

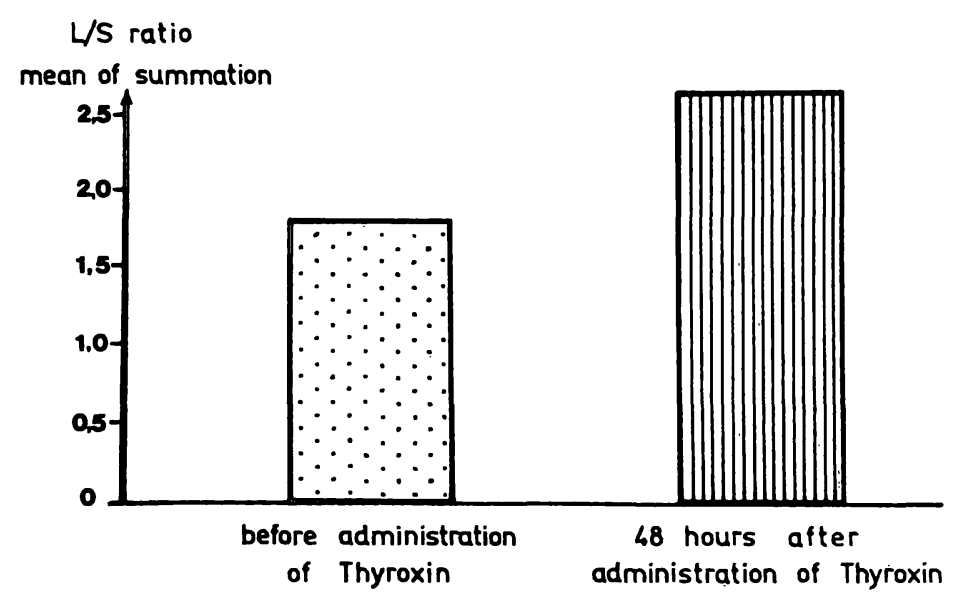

Figure 2. Effect of intraamniotically given thyroxin on L/S ratio.

This may be explained by the fact that the majority of deliveries occured several days after medication. The level of newborn venous blood was also normal in the 5th postnatal day showing euthyreoid values. During neonatal intensi- ve surveillance, no change was observed that could have been due to thyroxin effect.

In the period of investigation, 1584 deliveries were performed, 58 of which were serious and fairly serious toxemic pregnancies as defined by WITTLINGER. Thyroxin was not given in 40 cases for the following reasons: contraindication, premature rupture of membrane, fetal distress, intrauterine death and also when the test of amniotic fluid demonstrated fetal pulmonary maturity. These 40 cases were regarded as the nontreated group. The data obtained from the thyroxin treated group and the non-treated group are presented in table II.

Table II. Important data of the thyroxin treated group and the non-treated group and the neonatal outcome.

\begin{tabular}{|c|c|c|}
\hline & $\begin{array}{l}\text { Thyroxin } \\
\text { treated } \\
\text { group }\end{array}$ & $\begin{array}{l}\text { Non- } \\
\text { treated } \\
\text { group }\end{array}$ \\
\hline $\begin{array}{l}\text { Number of pregnant } \\
\text { women }\end{array}$ & 18 & 40 \\
\hline $\begin{array}{l}\text { Gestational age at } \\
\text { parturition } \\
\text { less than } 37 \text { weeks }\end{array}$ & $14(\sim 78 \%)$ & $31(77.5 \%)$ \\
\hline $\begin{array}{l}\text { Weight at birth } \\
\text { under } 2500 \mathrm{~g}\end{array}$ & $7(\sim 39 \%)$ & $12(30 \%)$ \\
\hline Mean of gestational age & 36.3 & 36.7 \\
\hline $\begin{array}{l}\text { Toxemia according to } \\
\text { WITTLINGER serious } \\
\text { (over } 20 \text { points) }\end{array}$ & $12(\sim 67 \%)$ & $22(55 \%)$ \\
\hline $\begin{array}{l}\text { Fairly serious } \\
\text { (between } 15-20 \text { points) }\end{array}$ & $6(\sim 33 \%)$ & $18(45 \%)$ \\
\hline $\begin{array}{l}\text { Perinatal loss: } \\
\text { intrauterine } \\
\text { post partum }\end{array}$ & $\begin{array}{l}1(56 \%) \\
1 \\
-\end{array}$ & $\begin{array}{l}7(\sim 175 \%) \\
5 \\
2\end{array}$ \\
\hline
\end{tabular}

Events of perinatal period:

\begin{tabular}{lll}
\hline Number of newborns & 17 & 35 \\
\hline IRDS development & - & $6(\sim 17 \%)$ \\
\hline Loss of HMB & - & $2(\sim 5 \%)$ \\
\hline Transient hyperbilirubinemia & $2(\sim 12 \%)$ & $4(\sim 11 \%)$ \\
\hline Infection in perinatal period & $1(\sim 6 \%)$ & $2(\sim 5 \%)$ \\
\hline
\end{tabular}


Although 7 of the 18 thyroxin treated pregnant women were delivered of premature infants, IRDS of HMB was not observed. Among the premature infants of the 40 toxemic pregnant women, who were not treated with thyroxin, IRDS was observed in 8 cases, and 2 of the infants were under $1500 \mathrm{~g}$ and died. In both cases the autopsy findings demonstrated hyaline membrane disease (in one of the two the direct cause being intracranial hemorrhage). In this thyroxin-non-treated group 5 additional infants were lost.

Five intrauterine deaths prior to delivery were due to toxemic placental insufficiency according to the autopsy findings.

The details of one of the fetal loss in the thyroxin-treated group are the following:

The gravida was in the 33rd gestational week was hospitalized with the diagnosis of preeclamptic toxemia. The delivery was induced because her blood pressure was $180-190 / 130$ torr despite medication. Her proteiunuria was rapidly progressing (to $28.7 \mathrm{~g} /$ day) in the collected urine, and in addition the estriol level was too low for measurement. An amniocentesis was performed before the induction and indicated pulmonary immaturity (Clements test: negative, L/S ratio: 1.2 , amniocrit: 0.20 , glucose: $2.4 \mathrm{mmol} / 1$, creatinine: $1.375 \mathrm{mmol} / \mathrm{l}$ ). Thus, thyroxin was given intraamniotically. Twenty-four hours after the medication, her temperature rose and intrauterine death occurred. The fetus weighed $2100 \mathrm{~g}$, and the autopsy could demonstrate only symptoms of intrauterine hypoxia. In this case, a role for thyroxin in the fetal loss cannot entirely be excluded.

\section{Discussion}

The dangers of preeclamptic toxemia both for the mother and the fetus are well known $[2,4$, $18,23]$. One of the most effective means of preventing complications is an induced preterm delivery. The greatest danger of a poorly timed preterm delivery is IRDS, due to pulmonary immaturity. In cases of serious toxemia, after steroid administration, the number of intrauterine deaths rise $[2,10,18]$. In recent years more authors reported that thyroxin stimulated the surfactant production. The role of $T_{3}$ and $T_{4}$ in fetal development has not been cleared up including the physiology. NIVELON [15] pointed out that $\mathrm{T}_{4}$ bound to a protein of great molecu- lar weight (TBG) cannot pass through the placental barrier. The level of maternal $\mathrm{T}_{4} \mathrm{can}$ influence that of the fetal's only in early pregnancy (under 18 weeks). He also proved that the $\mathrm{T}_{4}$ reaches the fetus via the amniotic fluid. The $T_{4}$ level of the amniotic fluid can be measured and its changes follow those from the fetal serum level. It was also established that in the fetus, the thyroid hormones favorably influence the growth of the bone structure, the development of the nervous system, the myelinization and increase the production of pulmonary surfactant in the II type pneumocytes $[1,5,6,8$, $17,19]$. Wu, KIKKAWA et al. [29, 30] proved that intraamniotically administered thyroxin increased the pulmonary surfactant level in laboratory animals. The action of mechanism presumably takes effect by accelerating the differentiation of a certain enzymetic system. Observations on patients are not unanimous. Intraamniotically administered $T_{4}$ is used not only for IRDS prevention but also for other therapies. WeINER et al. [28] attempted to treat proved fetal goiter in the 30th gestational week by intraamniotically applied $\mathrm{T}_{4}$. SCHREIER et al. [20] could not observe a decressed incidence of IRDS after intraamniotically administered $T_{3}^{3}$. MACHIACH et al. [11, 12] reported significantly decreasing incidence of IRDS following intraamniotically administered $\mathrm{T}_{4}$. DUDENHAUSEN [3] published similar results: after levothyroxin administration the lecithin level in the amniotic fluid significantly increased and, parallel with this, the observed number of hyaline membrane syndrome decreased. However, in the 22 cases examined, on five occasions fetal tachycardia could be observed 2 days after the thyroxin administration. In 1982 we reported [13, 25] favorable results obtained in a few cases; thus the drug has been used in a larger number of cases. On the basis of our results it is concluded that thyroxin, in the applied dose, brings about within 48 hours, an increase in the $\mathrm{L} / \mathrm{S}$ ratio as well as the Clements test used for determinations of pulmonary surfactant. The other parameters examined in the amniotic fluid, representing functional and somatic maturity, and the hormone estriol, HPL levels indicating the intrauterine state of the fetus, did not change 
due to thyroxin. Neither in the mother nor in the newborn was clinical side effect observed due to thyroxin prophylaxis. The $T_{4}$ was rapidly eliminated from the amniotic fluid. The postmedication $\mathrm{T}_{4}$ level in the fetus was gradually decreased depending on the time that elapsed until delivery, and on the 5th to 6th days following the thyroxin administration it was almost normal. On the post-natal 5 th day, the $\mathrm{T}_{4}$ levels of the venous blood taken from the newborn infants did not show any increase. The passage of the drug via amniotic fluid to the fetus presumably stops at the placenta barrier and the thyroxin does not reach the mother. This pre- sumption is supported by the fact that an increased thyroxin level was not observed in the maternal venous blood regardless of the time of administration. The placenta serves as a twoway barrier (mother-fetus, fetus-mother) for the drug. This is supported by our observation that following the intraamniotically administered $500 \mu \mathrm{g} \mathrm{L}$-Thyroxin, the maternal levels were not altered. In our opinion, in cases of serious and fairly serious preeclamptic toxemia, where the induction of labor is vital, in the interest of the fetus, intraamniotically administered LThyroxin can be effectively applied, though a premature birth can be inevitable.

\section{Summary}

In 18 cases of serious and fairly serious toxemic pregnancy, the authors gave $500 \mu \mathrm{g}$ L-Thyroxin "Henning" intraamniotically after the laboratory evaluation demonstrated negative pulmonary maturity from an amniotic fluid sample. Maternal and fetal complications due to the drug could not be observed. Despite a $39 \%$ premature incidence, IRDS and hyaline membrane disease were not observed. The administered $\mathrm{T}_{4}$ caused a positive change in the direction of the $\mathrm{L} / \mathrm{S}$ ratio and the Clements test. The other amniotic fluid parameters did not change, exept the $\mathrm{T}_{4}$ level. The extremly high $\mathrm{T}_{4}$ level obtained 48 hours later gradually became normal several days later. The $T_{4}$ values obtained from the blood of the mother and the newborn on the 5th postnatal day were normal. In toxemic cases where the induction of labor is vital and there is a risk of IRDS and steroid application in contraindicated, intraamniotic thyroxin is recommended as prophylaxsis for IRDS.

Keywords: Fetal pulmonary maturity, preeclamptic toxemia, thyroxin.

\section{Zusammenfassung}

Wirkung einer intraamnialen Thyroxingabe auf die Akzeleration der fetalen Lungenreife bei Präeklampsie

Bei 18 Schwangeren mit schwerer bzw. mäßiger präeklamptischer Symptomatik wurden $500 \mu \mathrm{g}$ L-Thyroxin „Henning" intraamnial appliziert. Zuvor hatte die laborchemische Untersuchung des Fruchtwassers eine fehlende Lungenreife ergeben. Wir konnten weder bei der Mutter noch beim Feten Komplikationen als Folge der Medikation beobachten. Trotz einer Frühgeburtsinzidenz von 39\% trat in keinem Fall ein RDS auf. Das applizierte $\mathrm{T}_{4}$ veränderte die L/S-Ratio im Fruchtwasser

Mots-clés: Fetale Lungenreife, Präeklampsie, Thyroxin. und das Ergebnis des Clements-Tests in positiver Richtung. Andere Parameter im Fruchtwasser veränderten sich mit Ausnahme des $\mathrm{T}_{4}$-Spiegels nicht. Der extrem hohe $\mathrm{T}_{4}$-Spiegel nach 48 Stunden normalisierte sich schrittweise einige Tage später. Die $\mathrm{T}_{4}$-Blutspiegel lagen am 5. Tag post partum bei Mutter und Kind im Normbereich. Ist eine Geburtseinleitung bei Präeklampsie vital indiziert und liegt das Risiko für ein RDS vor, so wird. bei Vorliegen einer Kontraindikation für Steroide die Prophylaxe eines RDS mittels intraamnialer Thyroxingabe empfohlen.

\section{Résumé}

Les effets de la thyroxine en injection intra-amniotique sur l'accéleration de la maturité pulmonaire fotale dans le préeclampsie

Les auteurs ont administré en intra-amniotique $500 \mu \mathrm{g}$ de $L$. thyroxin uenning» au cours de 18 grossesses avec toxémie grave ou assez grave après que le laboratoire ait montré une immaturité pulmonaire sur l'analyse du liquide amniotique. Il n'a pas été observé de complications maternelles ou fœtales secondaires au médicament. Il n'a pas été observé non plus de SDR ou de maladie 
des membranes hyalines malgré une incidence de prématurité de $39 \%$. La $\mathrm{T}_{4}$ administrée a positivé le rapport $\mathrm{L} / \mathrm{S}$ du liquide amniotique ainsi que le test de Clément. Les autres paramètres du liquide amniotique ne sont pas modifiés à l'exception du taux de $\mathrm{T}_{4}$. Le taux très élevé $\mathrm{de}_{4} \mathrm{~T}_{4}$ obtenu à $\mathbf{4 8}$ heures se normalise ensuite progressivement en quelques jours. Les valeurs de $T_{4}$ chez la mère et chez le nouveau-né étaient normales au cinquième jour du post-partum. Dans les cas de toxémie où l'induction du travail est vitale et où il y a un risque de SDR avec contre-indication. aux corticoïdes, les auteurs recommandent l'injection intra-amniotique de thyroxine comme prophylaxie de SDR.

Mots-clés: Maturité pulmonaire fotale, préeclampsie, thyroxine.

\section{References}

[1] Burmann KD, J Read, RC Dimond, GL Noel: Measurements of 3, 3,5-Triiodthyronine, 33-L-diiodothyronine, $\mathrm{T}_{3}$ and $\mathrm{T}_{4}$ in human amniotic fluid and in cord and maternal serum. J Clin Endocrinol Metab 43 (1976) 1351

[2] BüKY B: A retardált ujszülött. Magy Nőorv L 45 (1982) 101

[3] Dudenhausen JW: Wirkungen der intraamnialen Thyroxingabe auf den Feten. Geburtshilfe Frauenheilkd 44 (1984) 777

[4] Egyed J, M CsákáNy, I SZigetváRI, I Gáti: A szülés idöpontjának megválasztása kóros terhességben. Magy Nőorv L 45 (1982) 207

[5] Fisher DA, J Dussault, LJ ChOPRA: Ontogenesis of hypothalamic-pituitary thyroid function and metabolism in man, sheep and rat. In: Roy \& Green (eds): Recent Progress in Hormone Research, Vol. 33. Academic Press Inc, New York 1976

[6] GeNDRel D, L DEL VIGN: Abaissement de la thyroxine plasmatique et dessa protéine porteuse au cours des détresses respiratoires néonatales. Arch $\mathrm{Fr} \mathrm{Pe}-$ diatr 38 (1981) 401

[7] HoRváth I, I Fias, Sz Soós, K Méhes: Az ujszülöttkori respiratios distress syndroma megelőzése az anya szülés elötti dexamethason kezelésével. Orv Hetil 116 (1975) 195

[8] KIngstone D, AMB Bossi: Further observations on serum free thyroxine concentrations during pregnancy. Br Med J 283 (1981) 584

[9] LIGGINs GC, RN HowIE: A controlled trial of antepartum glucocortiocid treatment for prevention of the respiratory distress syndrome in premature infants. Pediatrics 50 (1972) 515

[10] LIGGINS GC, RN HowIE: The prevention of IRDS by maternal steroid therapy. In: GLuck L (ed): Modern Perinatal Medicine. Year Book Medical Publishers, Chicago 1974

[11] Mashiach S, G Barkai, J Sack, E Stern, B GoldMAN, M BRISH, DM SERR: Enhancement of fetal lung maturity by intra-amniotic administration of thyroid hormone. Am J Obstet Gynecol 130 (1978) 289

[12] Mashiach S, G Barkai, J Sack, E Stern, M Brish, B GOLDMAN, DM SERR: The effect of intraamniotic thyroxine administration on fetal lung maturity in man. J Perinat Med 7 (1979) 161
[13] B NAGY Z, G Józsa, I Veszelovszky: Intraamniálisan adott $L$-Thyroxin hatása a magzati tüdő érésére. Előadás a Magyar Gyermekorvosok Társasága és a Magyar Nőorvos Társaság Perinatális Szekciójának Tudományos Ülésén. Miskolc 1982

[14] NagY G, Z Kardos, M Asztalos: A respiratios distress syndroma szteroid profilaxisa diabeteses terhességben szülés alatt. Magy Nőorv L 40 (1977) 320

[15] Nivelon JL, D Tenenbaum: Le contionnement thyroidien fotal et neonatal. Pediatrie 35 (1980) 369

[16] Országos Szülészet-Nőgyógyászati Intézet közleménye. Tájékoztató a Perinatális Intenziv Centrumok 1978. évi forgalmáról. Magy Nőorv L 42 (1979) 453

[17] Redding RA, WHJ Douglas, M ST̃ein: Thyroid hormone influence upon lung surfactant metabolism. Science 175 (1972) 994

[18] RuZicsKa Gy, I TAKÁCs: Korai és késői terhességi toxicosis. Medicina, Budapest 1975

[19] SACK J, D DelberT; A Fisher, RW LAM: Thyroid hormone metabolism in amniotic and allantoic fluids of the sheep. Pediatr Res 9 (1975) 837

[20] SChreYer P, E Caspi, Y LetKo, R RoN-El, N PINTO, JL ZEIDMAN: Intraamniotic Triidothyronine installation for prevention of respiratory distress syndrome in pregnancies complicated by hypertension. J Perinat Med 10 (1982) 27

[21] SHINITZKY M, A GoldFisher, A BRUCK, B GoldMAN, E STERN, G BARKAI, S MASHIACH, DM SERR: A new method for assessment of fetal lung maturity. Br J Obstet Gynaecol 83 (1976) 838

[22] Szabó I, I Csaba, P Novák, I DrozgYik: A steroid therápia jelentősége az ujszülöttkori respiratorikus distress syndroma megelözésében. Orv Hetil 118 (1977) 566

[23] VÁCZY L: Terhességi toxaemia és disseminált intravasalis coagulopathia. Magy Nőorv L 40 (1977) 415

[24] VeSZELOVSZKY I: Idiopathiás respiratios distress syndroma megelőzése dexamethasonnal. Kandidátusi értekezés. Szentes 1979

[25] Veszelovszky I, Z B Nagy, A Szabó: A Magyar Nőorvos Társaság Dél-Magyarországi Decentrumának Tudományos ülésén "Törekvéseink a perinatális mortalitás csökkentésére" cimü kerekasztal konferencia. Szentes 1982 
[26] VeszelovszKy I, M VeszelovszKYnE GyöRfi, L PATAKI, L BóDIS, F SzonTÁGH: Antenatálisan adott Dexamethason az ujszülöttkori respiratios distress syndroma megelőzésére. Orv Hetil 117 (1976) 345

[27] Veszelovszky I, M VeszelovszKYnNE GyörFi, L PATAKI, L BóDIS: Elöadás a Szegedi Akadémiai Bizottság és a SZOTE Tudományos Úlésén: RDS profilaxis Dexamethasonnal. Szeged 1974

[28] WEINER S, JI SCHARP, RJ BOLOGNESE, RJ LIBRIzZI: Antenatal diagnosis and treatment of a fetal Goitre. J Reprod Med 24 (1980) 39

[29] WU B, Y KIKKaWA, MM Orgalesi, EK Motoyama, MM Kaibara, CJ Zigas, CD CoOK: The
Effect of Thyroxine on the Maturation of Fetal Rabbit Lungs. Biol Neonate 22 (1973) 161

[30] Wu B, Y KiKKaWA, MM ORgalesi, MM KaIbara: Accelerated maturation of fetal rabbit lungs by thyroxine. Physiologist 14 (1971) 253

Received January 2, 1985. Revised August 14, 1985. Accepted September 2, 1985.

Dr. Iván Veszelovszky Municipal Hospital, Szentes Dept. Obstetrics \& Gynecology Sima F. U. 44-58

H-6600 Szentes, Hungary 


\section{W. Voundereyeken}

R. Meermann

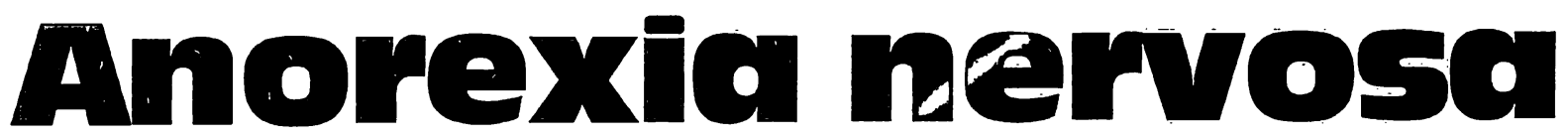

\section{A Clinician's Guide to Treatment}

1984. $17 \mathrm{~cm} \times 24 \mathrm{~cm}$. XIV, 251 pages.

Clothbound. DM 98,- ISBN 3110095319

Despite more than a century of ever-increasing scientific interest and research, anorexia nervosa - the pathological pursuit of thinness - still presents a challenge to clinicians throughout the world. It has become practically impossible to keep in touch with the constant proliferation of scientific literature on this subject. Moreover, the clinician (the general practitioner, the psychiatrist or the psychologist) needs, first and foremost, practical guidelines for his everyday therapeutic work with these patients.

Therefore, two experienced clinicians, who are daily involved in research and treatment of large numbers of anorexia nervosa patients, decided to write the first book dealing extensively with the many practical issues one is faced with when investigating and treating anorectic patients of all ages and in all stages of their illness. No single treatment modality, psychotherapeutic, pharmacologic or nutritional, has provided the final solution for the management of this intriguing syndrome. Hence, the therapeutic approach described in this book is characterized as an eclectic, broad spectrum or multimodal treatment in which strategies and interventions from different therapeutic models have been integrated.
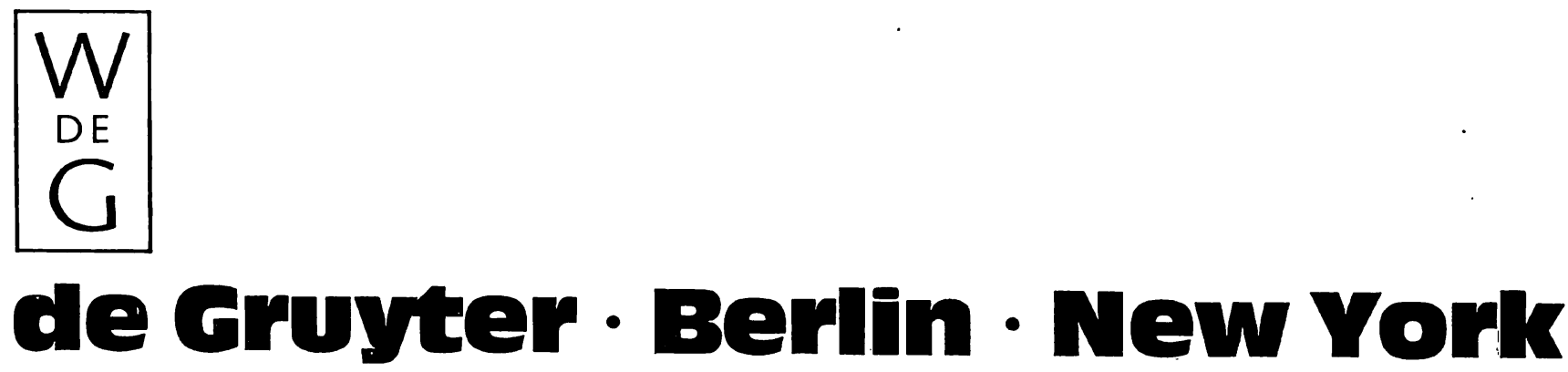